\title{
An interesting foreign body in the urinary system: Metal clips
}

\section{Üriner sistemde sıradışı bir yabancı cisim: Metal klips}

\author{
Cem Şenol ${ }^{1}$, Coşkun Kaya ${ }^{2}$
}

\begin{abstract}
Migration of surgical materials into the urinary system is a rare situation. Forgotten and/or fragmented ureteral stents were defined more frequently as foreign bodies in urinary system in the literature. But surgical clips migration is an interesting case. In this paper, we aim to present a 31 -year-old man with a medical history of multiple urinary operations. We extracted two metal clips, one of them was from the ureter and the other from the renal pelvis of this patient. The case is discussed in the light of the literature.

Keywords: urinary system, metal clips, foreign body
\end{abstract}

${ }^{1}$ Dr.Nafiz Korez Sincan State Hospital, Department of Urology, Ankara, Turkey.

${ }^{2}$ Eskisehir City Hospital, Department of Urology, Eskisehir, Turkey.

\section{(iD)}

CS: 0000-0002-8099-0571

CK: 0000-0002-7445-2304

Informed Consent: The written consent was received from the patient who was presented in this study.

Hasta Onamı: Çalışmada sunulan hastadan yazılı onam alınmıştır.

Conflict of Interest: No conflict of interest was declared by the authors.

Çıar Catışması: Yazarlar çıkar çatışması bildirmemişlerdir.

Financial Disclosure: The authors declared that this case has received no financial support. Finansal Destek: Yazarlar bu olgu için finansal destek almadıklarını beyan etmişlerdir.

Gelis Tarihi / Received: 31.10 .2020

Kabul Tarihi / Accepted: 08.03.2021

Yayın Tarihi / Published: 01.04.202

Sorumlu yazar / Corresponding author:

Coşkun Kaya

Adres/Address: Eskisehir City Hospital, Department of Urology, 71 Evler Mah. Çevre Yolu, 26080, Eskisehir, Turkey.

e-mail: coskun_kaya2008@yahoo.com

Tel/Phone: +905064434154

\section{Copyright $\odot$ ACEM}




\section{Introduction}

Surgical material migration into the urinary system does not occur frequently. Foreign bodies detected in the urinary system in urological surgeries can usually be together with stones. Although the most common foreign bodies are urinary stents and stent residues, metallic clips used for bleeding control can also be encountered in the urinary tract.

We present a case of migration of a metal clip into the right ureter 12 years after an operation for right kidney calculi.

\section{Case report}

A 31-year-old man was referred to our clinic with symptoms of right flank pain, hematuria, and dysuria for two months leading up to our consultation. In his medical history he had undergone urinary operations seven times, he was unaware what these were for, he only knew that they were performed for stones in his urinary system. We received the information that no other abdominal organ surgery was performed. In a physical examination, we found he had four laparoscopic port entry scars on the right side of the abdomen and a $20 \mathrm{~cm}$ median abdominal incision. His renal functions were normal, and he had microscopic hematuria in a urine analysis. We performed a plain abdominal radiograph and a non-contrast computerized tomography (CT) after the urinary ultrasonography showed bilateral hydroureteronephrosis (Figure 1,2). The CT showed a 7 $\mathrm{mm}$ long right ureteral stone in the distal ureter, another stone in the right kidney, and grade 4 hydroureteronephrosis in proximity to the stone in the distal ureter (Figure 2).

We decided to perform a ureterorenoscopy of the right ureter and reached the stone, and holmium laser lithotripsy was performed. Inside the stone we saw a metal fragment. After all the stone was cleared, we removed the metal fragment from the ureter with forceps and we saw that it was a metal clip, as used in laparoscopic procedures to control bleeding (Figure 3). We inserted a double $\mathrm{j}$ catheter into the right ureter. In the following month we performed a second ureterorenoscopy for the kidney stone. We removed the double $\mathrm{j}$ catheter out of the ureter and in the renal pelvis we saw another metal clip with a stone covering it, which was lodged into the renal pelvis wall. Holmium laser lithotripsy was performed, the stone was cleared, and the metal clip was extracted from the renal pelvis. A double $\mathrm{j}$ catheter was again inserted into the right ureter. Post-operative first day plain abdominal radiography was performed and there was no evidence of any residual stone or foreign body.

Written informed consent was obtained from patient for publication..

\section{Discussion}

A foreign body can reach the urinary tract by retrograde migration from the bladder, during the operation, from the intestinal tract, or after renal trauma [1]. Forgotten and fragmented ureteral stents have been defined more frequently as foreign bodies in the urinary system in the literature. Stone encrustation on such forgotten ureteral stents may cause complications and further medical approaches would then be needed. [2]. Similar cases, such as ours, have been reported by Miller et al. [3], Massud W [4], Brusky et al. [5]. In our case, we think that our patient had initially undergone a laparoscopic pyelolithotomy, but, surgical clips were applied and one of the metal clips fell in the collecting system because of bleeding during the surgery. There have been case reports of clips migrating to the urinary system after the partial nephrectomy
$[6,7]$. So, the migrating of the clips should be kept in mind and the patients should be informed after the laparoscopic pyelolithotomy like the partial nephrectomy.

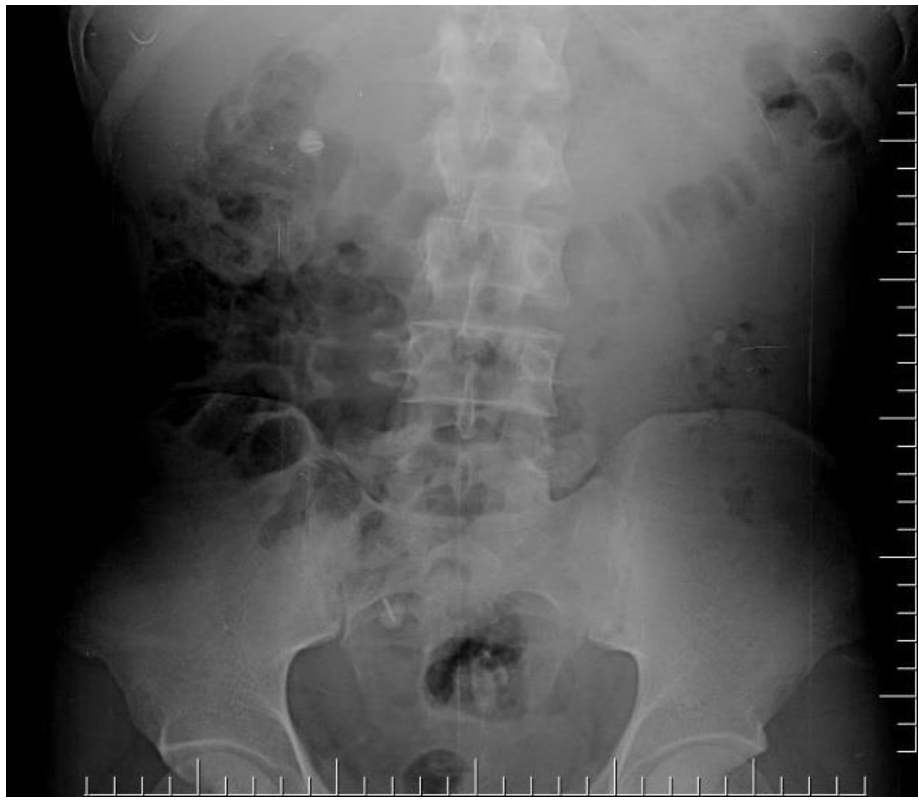

Figure 1: Plain abdominal radiograph of the patient.

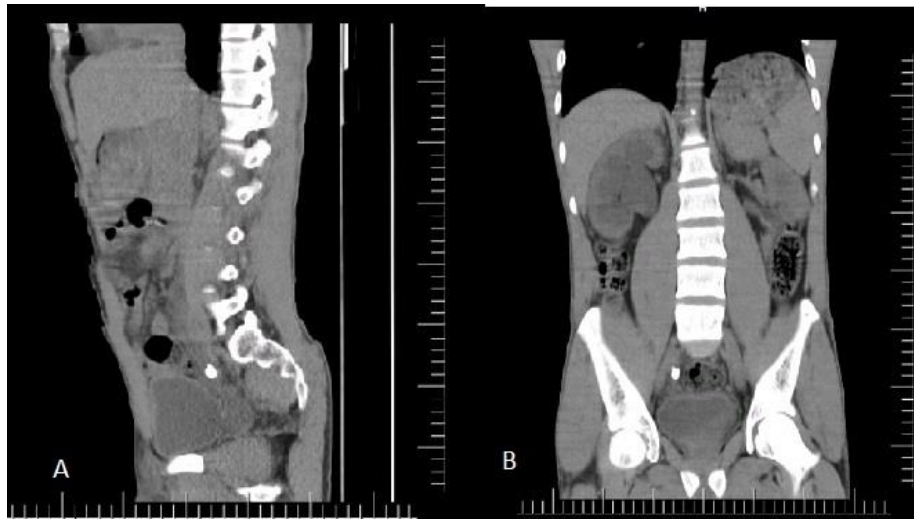

Figure 2: a. Sagittal plane image of the stone and the metal clips, $b$. Coronal plane image of the metal clip in the stone settled in the ureter.

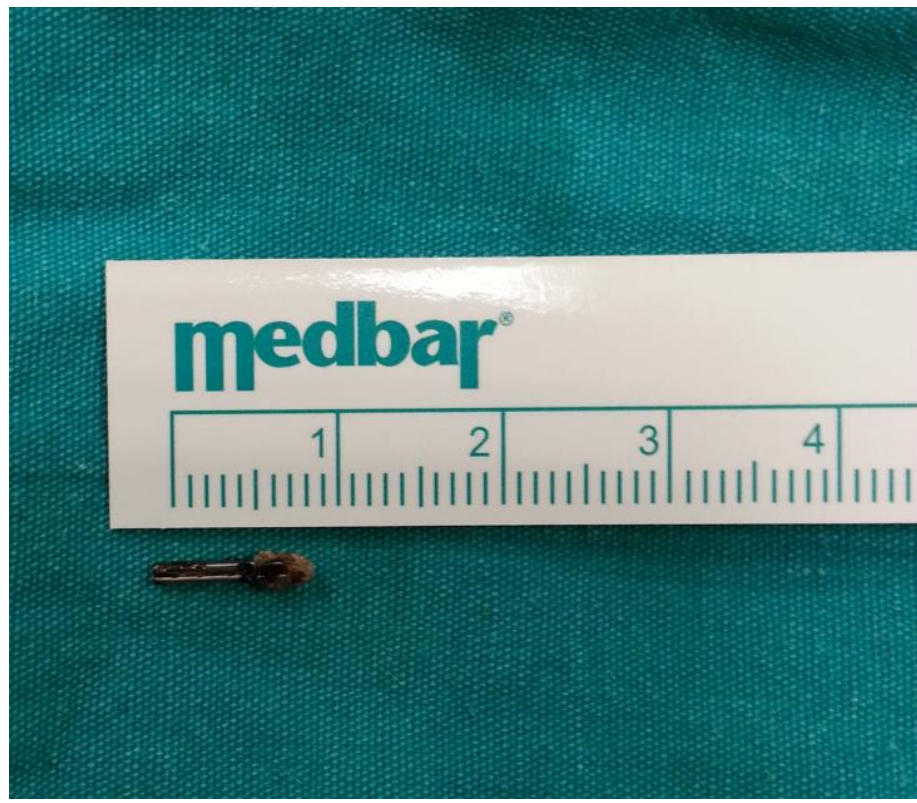

Figure 3: The metal clip which had been extracted from the ureter.

In conclusion, surgical clips are useful tools in laparoscopic cases, but we should keep in mind that over time they may migrate other than the anatomic area where they were 
used, and we should consider the possibility of clip displacement in patients with follow-up complaints, otherwise it may cause serious problems in the future.

\section{References}

1. Inai $\mathrm{T}$, Hiraishi $\mathrm{K}$, Kurokawa $\mathrm{K}$. Foreign body in the kidney. Br $\mathrm{J}$ Urol. 1987;59:360.

2. Dell'Abate P, Del Rio P, Soliani P, Colla G, Sianesi M. Choledocholithiasis caused by migration of a surgical clip after video laparoscopic cholecystectomy. J Laparoendosc Adv Surg Tech A. 2003;13:203-4.

3. Miller M, Anderson JK, Pearle MS, Cadeddu JA. Resorbable clip migration in the collecting system after laparoscopic partial nephrectomy. Urology. 2006;67:845.e7-8.

4. Massoud W. Spontaneous migration of a surgical clip following partial nephrectomy. Urol J. 2011;8:153-4.

5. Brusky JP, Tran VQ. Resorbable clip migration resulting in ureteral obstruction and sepsis after laparoscopicpyeloplasty. J Endourol. 2010;24:1563-4.

6. Lee Z, Reilly CE, Moore BW, Mydlo JW, Lee DI, Eun DD. Stone formation from nonabsorbable clip migration into the collecting system after robot-assisted partial nephrectomy. Case Rep Urol. 2014;2014:397427.

7. Bayles AC, Bhatti A, Sakthivel A, Naisby G, Gowda B. "Clipstrasse": A novel complication following partial nephrectomy. Scand J Urol. 2015;49:424-5. 